Received : July 21, 2021

Accepted : August 16, 2021

Published : October 13, 2021
Homepage: http://trj.stptrisakti.ac.id/index.php/trj/index DOI: https://doi.org/10.30647/trj.v5i2.123

Tourism Research Journal

E-ISSN: 2598-9839

2021, Vol. 5 No. 2

\title{
SWOT Analysis Nomadic Tourism as Millennial Friendly Natural Tourist Destination Development Strategy (Case Study: Glamping De Loano, Purworejo)
}

\author{
Gratia Wirata Laksmi, Myrza Rahmanita*, Himawan Brahmantyo, \\ Nurbaeti
}

Trisakti School of Tourism

*myrzarabmanita@stptrisakti.ac.id

\begin{abstract}
The purpose of this study is to analyze the alternative strategy of developing local tourism around Borobudur, one of the world's heritage as the top choice of foreign and domestic tourists, that focused on developing a variety of alternative tourism infrastructures while preserving the environment that is a millennial-friendly destination that is called Nomadic Tourism in Glamping De Loano, Purworejo, Indonesia. The research took place between June-July 2020 in Glamping De Loano, Purworejo. The chosen methods including documentation, observation, and interviews with local government groups, visitors, and residents. Glamping De Loano is a new and fresh tourism sensation in Purworejo that can bring millennial tourists and new unique tourism experiences to the area. It is a new earlystage of destination because it has only been operated for less than a year but has many opportunities that can be cultivated and developed. However, most complaints coming from them are regarding narrow and dangerous road infrastructure towards the destination, supporting ecosystem readiness, and conformity of the biophilic material to the environment surrounding. Most interviewers suggest it would be better with improved road infrastructure construction and focus on providing a basic supporting ecosystem. Recommendations are made for developing the Glamping De Loano tourism better to improve the experience of tourists and visitors and to improve the resident's quality of life. It is hoped that this research may prompt local authorities to take 1 residents' perceptions and experiences into account by creating better management measures and regulations.
\end{abstract}

Keywords: Nomadic Tourism, Destination Development Strategy, Glamping, Purworejo, Borobudur

Tourism Research Journal, Volume 5 (2), 2021 
SWOT Analysis Nomadic Tourism as Millennial Friendly Natural

Tourist Destination Development Strategy

(Case Study: Glamping De Loano, Purworejo)

\section{A. Introduction}

Borobudur is recognized as one of the world's heritage as the top choice of foreign and domestic tourists. Borobudur was issued as one of the top priorities of Indonesia's tourism destination. Thus, in 2019, the government puts foreign tourists' arrival target that is 1 million international foreigner tourists, two times higher than its previous achievement. In 2020, pandemic hit and tourist arrival went drop almost $88 \%$ from last year. This becomes a major concern to Indonesia since tourism is one of the biggest top contributors to Indonesia's national income (Tunjungsari, 2020).

Borobudur temple is considered to have potential needs to be unleashed. Seeing from good case practice from Angkor Wat that able to reach foreign tourists arrival ten times higher than Borobudur temple. Thus, the government of Indonesia aims high for Borobudur to become one of the contributors for Indonesia. However, due to the carrying capacity standard of Borobudur, Borobudur is not able to accommodate the high number of tourists. Thus it is necessary to develop supporting attractions and accommodation/amenities to support the ambitious goal (Hermawan et al, 2016).

Purworejo is located around 30 minutes from Borobudur and has tons of promising potentials to discover. It has hidden natural tourism, cultural tourism, and man-made (adventure) tourism runs by the local community. The tourism sector in Purworejo is sustained by the availability of its nature that has not been explored and managed optimally yet. The lack of tourism development, especially related to basic infrastructure, has resulted in the tourism industry in Purworejo Regency is unable to compete with the neighborhood areas, such as Kebumen, Magelang, Wonosobo, and Jogjakarta (Hidajat et al, 2020).

Nomadic tourism is considered to bring a new style of tourism, especially a new concept of millennial-friendly natural tourism in Indonesia. Indonesia is rich in the beauty of nature. There are many ways to enjoy the natural beauty of Indonesian nature. However, one of the ways to experience that is through nomadic tourism experience (Prabawa \& Pertiwi, 2020).

Millennials are one of the emerging demography which becomes one of the emerging industries. Millennials have unique characteristics when it comes to traveling. They put traveling as one of their life priority. They seek authentic and meaningful experiences. The tourism industry needs to discover the right strategy to win the millennial market (Pramono et al, 2020).

Departing from the trend of nomadic tourists, the concept of nomadic tourism in Indonesia was sparked off at the National Coordination Meeting 2018 of the Ministry of Tourism on 22-23 March 2018. Referring to (Kemenpar, 2018), nomadic tourism can be an affordable and quick solution in the world of tourism development, especially related to the acceleration of local tourism development which is considered unplanned in terms of accessibilities and amenities but has an 
SWOT Analysis Nomadic Tourism as Millennial Friendly Natural

Tourist Destination Development Strategy

(Case Study: Glamping De Loano, Purworejo)

extraordinary attraction for tourism potential. Indonesia makes tourism as the leading sector, of course, not only to increase the budget but also need a strategic agenda so that the development of the tourism sector will not have optimal results (Rahmanita, 2015).

The Ministry of Tourism in 2018, launched nomadic tourism in three locations in Indonesia which are part of ten tourism destination priorities, namely The Kaldera with Glamping The Kaldera on Lake Toba, North Sumatra, Borobudur Highland Park with Glamping De Loano in Purworejo, Central Java, and Labuan Bajo. Glamping De Loano is located in Sedayu Village, Loano District, Purworejo Regency, Central Java which is managed by the Badan Otorita Borobudur. Glamping De Loano is the main attraction of the Borobudur Highland Park which was built and developed as a goal to support the attractions of the Borobudur temple and is expected to attract foreign tourists. Glamping De Loano only takes three months of the development process and was officially opened in April 2019 for the public, to be precise one month after the inauguration on February 14, 2019 by Mr. Arief Yahya as Minister of Tourism 2015 - 2019.

Uniquely, Glamping De Loano is not only functioning as an alternative accommodation but also as an attraction. The environment around Glamping De Loano is rich in natural, cultural, and man-made attractions and has the potential to become supporting attractions of Glamping De Loano. Glamping De Loano is part of two regencies, Purworejo and Kulonprogo also support tourists who come to taste the natural and cultural attractions of the two districts (Pemkab Purworejo, 2021).

Glamping De Loano is located in a strategic location that interjects between two Yogyakarta city icons, namely the Borobudur temple and New Yogyakarta International Airport/NYIA. It only takes about 45-60 minutes from Borobudur Temple and 30 minutes from NYIA Airport which can be reached using private vehicles. Apart from its strategic location, this is not accompanied by accessibility to the location, there is no mode of public transportation to Glamping De Loano and road infrastructure to the Glamping De Loano location, which is a narrow road with winding inclines or steep descents (Badan Otorita Borobudur, 2019).

This study discusses the driving factors (strengths and weaknesses) and pulls factors (opportunities and threats) in developing nomadic tourism in Glamping De Loano Purworejo. Then strategies that need to be developed for nomadic tourism according to Glamping De Loano Purworejo.

The development of nomadic tourism in Glamping De Loano is very important because this destination will be the main attraction of Borobudur Highland Park and to attract foreign tourists. It is also being highly supported by the government both from the ministry, regional and local/village level. It is being developed as a millennial-friendly natural destination (Gatra.com, 2019). 
SWOT Analysis Nomadic Tourism as Millennial Friendly Natural

Tourist Destination Development Strategy

(Case Study: Glamping De Loano, Purworejo)

As mentioned, the concept of nomadic tourism is considered a new tourism approach in Indonesia and Glamping De Loano is one of the case practices that is successfully built, developed, and opened for the public. Although it is considered a new stage of establishment, however, Glamping De Loano has made tremendous progress regarding visitation. Glamping De Loano shows its potential to become not only the main attraction of Borobudur, but since it is officially located in the area of Purworejo, thus it can bring a huge impact towards Purworejo as well. If nomadic tourism strategy is proven to bring more visitors and tourists to the region while successfully maintain the sustainability of the environment by using biophilic and natural-friendly material, it would be beneficial for many stakeholders especially it would bring prosperity to the local society, as well (Sari et al, 2019).

The purpose of this study is to analyze the alternative strategy of developing local tourism around Borobudur, one of the world's heritage as the top choice of foreign and domestic tourists, that focused on developing a variety of alternative tourism infrastructures while preserving the environment that is a millennial friendly destination that is called Nomadic Tourism in Glamping De Loano, Purworejo, Indonesia.

\section{B. Literature Review \\ Nomadic Tourism}

Nomadic tourism that is being chosen to become the theoretical concept and foundation for this research study is the theory developed by the ministry of tourism in Indonesia in 2019. Indonesia's national strategy of tourism development was to develop 10 destination priorities which some of which are located in an area that still lacks or does not have adequate infrastructure and it is required a long time to develop the area. Tourism development with the concept of nomadic tourism is developed and tested to become the solution to equalization of the economy of the country through tourism. It is being pushed on the agenda since tourism is becoming one of the biggest contributors to Indonesia's economic income (Mahadewi, 2019).

That is being developed as the strategy to become a solution that needs a quick relatively fast and affordable compares to the development of using permanent tourism infrastructure development. Nomadic tourism is a new tourism style where tourists can stay for a certain period in a tourist destination with portable and mobile amenities (Kemenpar, 2019). Nomadic tourism has its uniqueness that is focused on unpopular location, vacation practices that include places that are hard to reach, create trip and holiday preferences that come from travel experiences (Ferreira, Helms, Brown, \& Lampinen, 2019). It has its specialty which is flexibility and surprises (Ferreira et al, 2019). 
SWOT Analysis Nomadic Tourism as Millennial Friendly Natural Tourist Destination Development Strategy (Case Study: Glamping De Loano, Purworejo)

In this research study, the research will also talk about the tourism development that reflects on tourism destinations. Nomadic tourism destination has its distinguished elements that are mentioned on research questions which are the nomadic attraction, nomadic amenity, nomadic accessibility, and nomadic supporting environment. The distinguished element of nomadic tourism elements are nomadic tourism infrastructure has infrastructure characteristics that embed to the nature (biophilic) and offer direct interaction experience with the local community. The diagram below will show the broad definition of unique differences of nomadic tourism elements compare to other tourism elements:

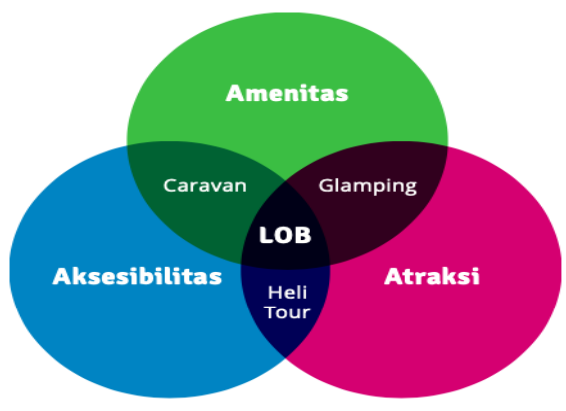

Figure 1: Nomadic Tourism

Source: Kemenpar (2019)

The nomadic destination has its uniqueness that reflects on its tourism elements that each element of nomadic tourism will be merged between each other and intersect and complement each element to another will create a unique nomadic tourism product that creates the total experience.

\section{SWOT Analysis}

SWOT strategic analysis is to identify various factors systematically to form strategy (Rangkuti, 2015). SWOT analysis is designed to form a short-term or longterm strategy to help create an important decision regarding various problems and issues. The output will be formed in the SWOT model that is composed of internal factors (strength and weakness) and external factors (opportunity and threat).

Table 1. SWOT Matrix Analysis

Tourism Research Journal, Volume 5 (2), 2021 
SWOT Analysis Nomadic Tourism as Millennial Friendly Natural

Tourist Destination Development Strategy

(Case Study: Glamping De Loano, Purworejo)

\begin{tabular}{|l|l|ll|}
\hline External Internal & $\begin{array}{l}\text { Strength (S) } \\
\text { Decide internal strength } \\
\text { factor }\end{array}$ & $\begin{array}{l}\text { Weakness (W) } \\
\text { Decide internal weakness } \\
\text { factor }\end{array}$ \\
\hline \begin{tabular}{l} 
Opportunity (O) $\begin{array}{l}\text { Decide external } \\
\text { opportunity factor }\end{array}$ \\
\hline $\begin{array}{l}\text { Threat (T) } \\
\text { Decide external threat } \\
\text { factor }\end{array}$
\end{tabular} & $\begin{array}{l}\text { ST (Strength and Threat) } \\
\text { Strategy }\end{array}$ & $\begin{array}{l}\text { OW (Opportunity and } \\
\text { Weakness) strategy }\end{array}$ \\
\hline
\end{tabular}

Source: Rangkuti (2015)

SWOT analysis can be used to formulate possible alternatives to develop nomadic tourism in Glamping De Loano. Combination of SWOT components is the strategy to support the development of tourism destination potential, for instance: (1) SO Strategy: to form a strategy that using strength to takes advantage of the opportunity; (2) ST Strategy: to form a strategy that using strength to prevent threat; (3) OW Strategy: to form a strategy that minimizes weakness to takes advantage of the opportunity; (4) TW Strategy: to form a strategy that minimizes weakness to prevent the threat

\section{Research Methodology}

This research uses a descriptive analysis method with a qualitative approach. This research uses a case study method with a phenomenological form. In preparing this thesis the writer researched by taking the object of research at Glamping De Loano, which is located in Purworejo, Sedayu Village, Loano District, Purworejo Regency, Central Java. The study runs from June to July 2020.

This research is started with the observation of the location and gather the necessary information that will be beneficial to the research. Firstly, we are going to identify the problems that become the main research of the topic. After problems are analyzed we can analyze the potential for tourism development in Glamping De Loano. After that, we will be able to validate all information with the selected interviewers that represent the important stakeholder groups while interviewing to analyze the tourism development through SWOT analysis.

To analyze the interview result according to the research variable that is formed in interview questions is using SWOT analysis to identify all factors systematically to form the right strategy for development Glamping De Loano. A SWOT analysis consists of the evaluation of internal factors (consisting of strengths and weaknesses and external (consisting of opportunities and threats). Based on the SWOT matrix analysis, various possible alternative strategies for developing nomadic tourism in Glamping De Loano can be formulated. The combination of SWOT components is a strategy that supports the development of potential tourist destinations such as Strengths Opportunities (SO), Strengths 
SWOT Analysis Nomadic Tourism as Millennial Friendly Natural Tourist Destination Development Strategy (Case Study: Glamping De Loano, Purworejo)

Threats (ST), Weaknesses Opportunities (WO), and Weaknesses Threats (WT). This research study will present this strategy as the main result.

This research is using several data collection techniques that are documentation, observations and, interviews. Interviews are being conducted to find answers based on the indicators that are mentioned on research variables to selected stakeholders that gave valuable insights for the research that are representing important groups of stakeholders which are the Glamping De Loano representative, flashpacker and millennial tourists, local governments representative which is the head of the village of Sedayu Village and the head of Tourism and Culture Department in Purworejo, Indonesia.

\section{Result}

The SWOT analysis tool is used to extract from the elaboration of the amenities, attractions, and accessibility variables of Glamping De Loano. The SWOT results are divided into four aspects, namely attractiveness, amenities, accessibility, and the supporting ecosystem:

Table 2. The SWOT Analysis of Glamping De Loano for Amenities

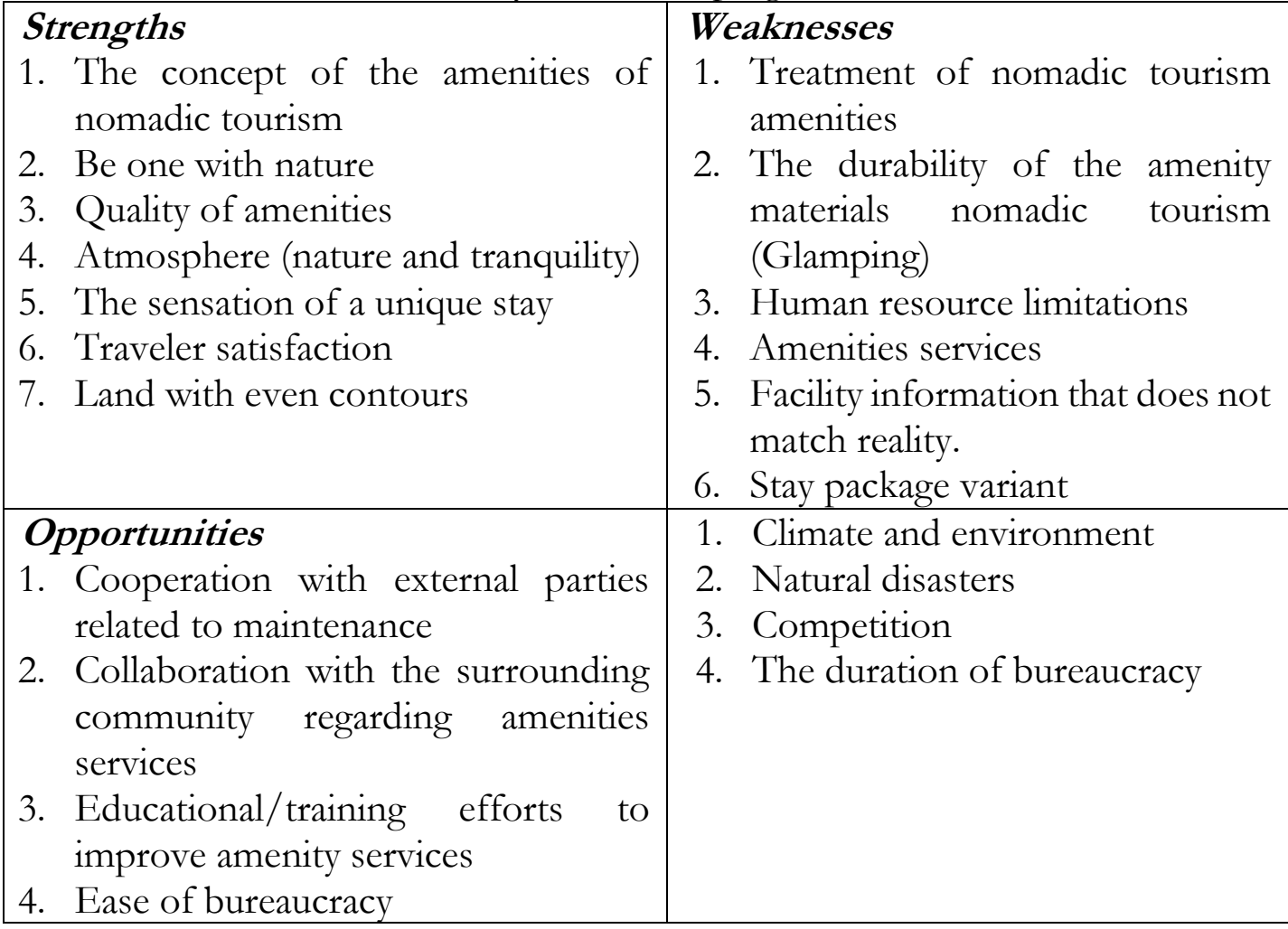

Source: Processed Data (2021) 
SWOT Analysis Nomadic Tourism as Millennial Friendly Natural

Tourist Destination Development Strategy

(Case Study: Glamping De Loano, Purworejo)

Table 3. The SWOT Analysis of Glamping De Loano for Attraction

\section{Strengths}

1. Potential place

2. Attraction surroundings

3. Natural attractions

4. Local attractions: Sedayu Digital Market

5. Events organized by Glamping De Loano

6. Natural landscape

7. Land with even contours

8. Attraction safety protocols

9. Downhill track

10. Amphitheater

11. Offroad Travel

\section{Weaknesses}

1. Limited human resources

2. Less diverse attractions

3. Availability and quality of information systems related to attractions

4. Attraction board

5. Education to the public/public about nomadic tourism

6. Destination information board

7. Spot photos that are less diverse and less authentic

8. Limited modes of transportation

9. Online and offline promotion is still lacking

10. Limitations of supporting facilities

\section{Threats}

Opportunities

1. Natural environment

2. Competition

3. Permission community for cultural attractions (art performances) with the surrounding community

3. The Cultural heritage of the surrounding community

4. Attractions of interest have an adjacent location

5. Potential serious leisure (tour packages for digital nomads/ flashpackers and luxpackers)

6. Outbound attractions

7. Attractions for millennials

8. Guests in the group

9. Collaboration with tour and travel (open trip package)

Source: Processed Data (2021) 
SWOT Analysis Nomadic Tourism as Millennial Friendly Natural

Tourist Destination Development Strategy (Case Study: Glamping De Loano, Purworejo)

Table 4. The SWOT Analysis of Glamping De Loano for Accessibilities

\section{Strengths}

\section{Weaknesses}

1. Infrastructure support (Road 1. Extreme road access development) 2. Road quality

2. Can be accessed from various 3. Lack of supporting facilities for paths

3. The location is quite close to the NYIA international airport accessibility (signs, street lighting)

4. Attraction board

5. Signposts

6. Lack of transportation modes that can be accessed directly

\section{Opportunities}

\section{Threats}

1. Support from various parties who helped to build roads (government

1. Narrow road (Gelang Projo) and the surrounding community)

2. Ease of bureaucracy

3. Cooperation with tour \& travel

4. Cooperation with the Department of Transportation

5. Cooperation with the private sector regarding the provision of public transportation

Source: Processed Data (2021) 
SWOT Analysis Nomadic Tourism as Millennial Friendly Natural

Tourist Destination Development Strategy

(Case Study: Glamping De Loano, Purworejo)

Table 5. The SWOT Analysis of Glamping De Loano for Supporting Ecosystem

\section{Strengths}

1. Strategic location

2. Cleanliness and safety (toilets, places of worship, trash cans, etc.)

3. Provision of clean water

\section{Weaknesses}

1. Power source

2. Limited support facilities promised (internet and heater)

3. Availability of supporting facilities

4. Availability and quality of related information systems

5. Promotion limitations

6. Maintenance of supporting facilities made from natural (bamboo)

7. The durability of supporting facilities made from nature (bamboo)

8. Cafeterias

9. Limited lighting

10. Destination security system

\section{Threats}

\section{Opportunities}

1. Cooperation related to services with the surrounding community

The openness of the local community to cooperate

2. Community empowerment

3. Public awareness of cleanliness

4. Public awareness

5. Natural quality (natural ecosystems and water sources)

6. Cooperate with online travel agents regarding the booking platform

Source: Processed Data (2021) 
SWOT Analysis Nomadic Tourism as Millennial Friendly Natural

Tourist Destination Development Strategy (Case Study: Glamping De Loano, Purworejo)

These SWOT factors are formulated into strategies for developing nomadic tourism destinations:

Table 6. Amenities Development Strategy

\begin{tabular}{|c|c|c|c|}
\hline $\mathrm{SO}$ & Nomadic & amenities & 1. Glamping Treatment \\
\hline ST & $\begin{array}{l}\text { development } \\
\text { involves the } \\
\text { community }\end{array}$ & $\begin{array}{l}\text { strategy that } \\
\text { surrounding }\end{array}$ & 2. Glamping facility upgrade \\
\hline $\mathrm{WO}$ & $\begin{array}{l}\text { Amenities quality } \\
\text { strategy }\end{array}$ & y improvement & $\begin{array}{l}\text { 1. Improving the quality of } \\
\text { human resources related to } \\
\text { improving Glamping } \\
\text { services } \\
\text { 2. Collaboration with the } \\
\text { surrounding community } \\
\text { regarding improving the } \\
\text { quality of amenities }\end{array}$ \\
\hline
\end{tabular}

Table 7. Accessibility Development Strategy

\begin{tabular}{|c|c|c|}
\hline $\mathrm{SO}$ & & 1. Development of access \\
\hline $\mathrm{ST}$ & & 2. Road quality improvement \\
\hline $\mathrm{WO}$ & & 3. Cooperation modes of \\
\hline WT & $\begin{array}{c}\text { Accessibility development } \\
\text { strategy }\end{array}$ & $\begin{array}{l}\text { public transportation } \\
\text { 4. Procurement of accessibility } \\
\text { support facilities }\end{array}$ \\
\hline
\end{tabular}

Source: Processed Data (2021)

Table 8. Attraction Development Strategy

\begin{tabular}{|c|c|c|}
\hline $\mathrm{SO}$ & MICE development strategy & $\begin{array}{l}\text { Cooperation with private } \\
\text { parties/sponsors to increase the } \\
\text { volume of events in Glamping De } \\
\text { Loano. }\end{array}$ \\
\hline $\mathrm{ST}$ & Attraction development strategy & $\begin{array}{l}\text { 1. Offer tour packages } \\
\text { 2. Addition of tourist attractions }\end{array}$ \\
\hline $\begin{array}{l}\text { WO } \\
\text { WTT }\end{array}$ & $\begin{array}{c}\text { Community-based tourism } \\
\text { strategy }\end{array}$ & $\begin{array}{l}\text { 1. Cooperation in the } \\
\text { development of tourist } \\
\text { attractions with the } \\
\text { surrounding community. } \\
\text { 2. Glamping De Loano } \\
\text { development cooperation by } \\
\text { involving the surrounding } \\
\text { community }\end{array}$ \\
\hline
\end{tabular}

Source: Processed Data (2021)

Tourism Research Journal, Volume 5 (2), 2021 
SWOT Analysis Nomadic Tourism as Millennial Friendly Natural

Tourist Destination Development Strategy (Case Study: Glamping De Loano, Purworejo)

Table 9. Supporting Ecosystem Development Strategy

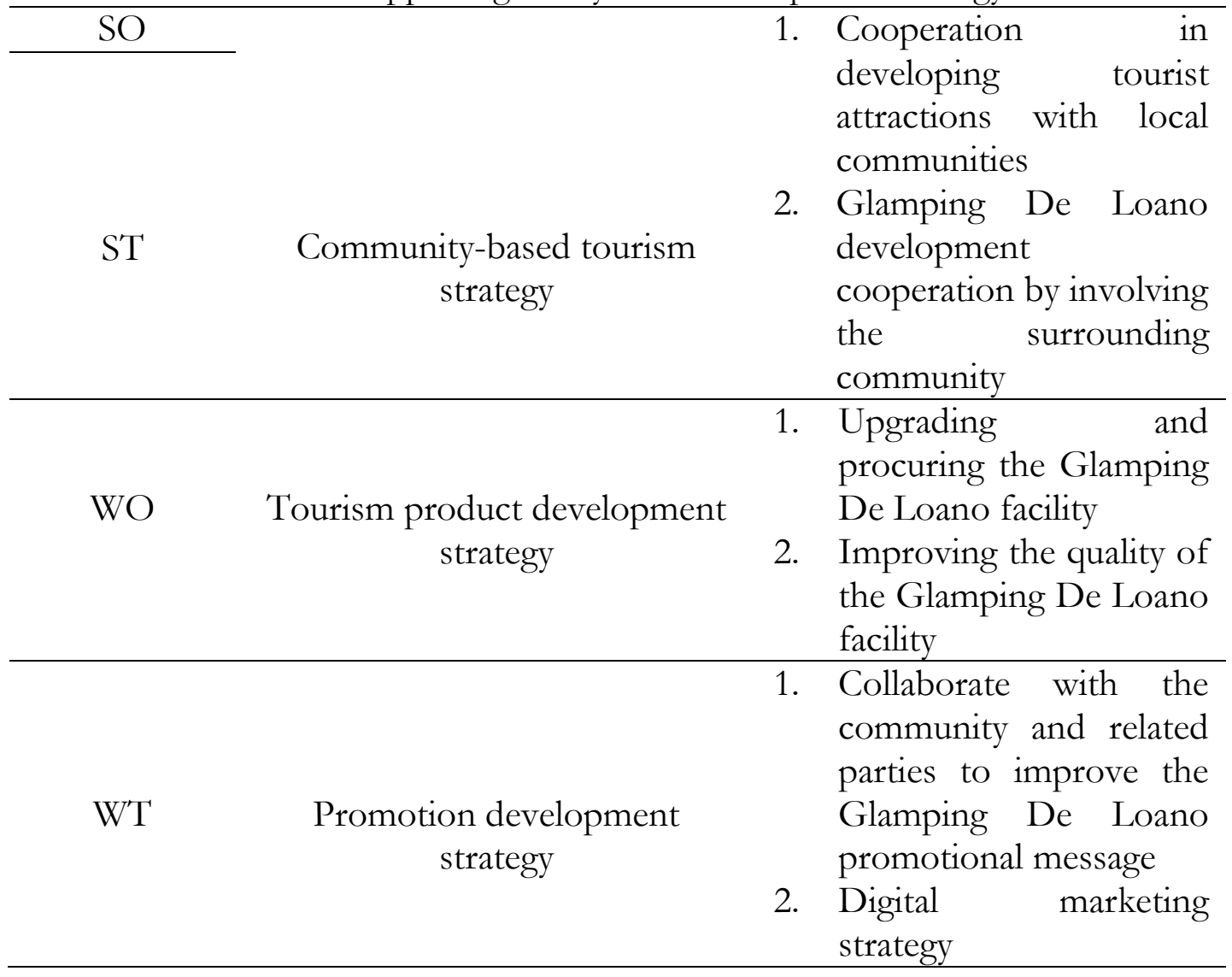

\section{E. Discussion}

\section{Nomadic Tourism Amenities Readiness Analysis}

The first discussion discussed the readiness analysis for nomadic amenities, which consisted of discussions related to the legality of amenities; amenity designs and themes; amenities facilities; amenities services; and security and safety of amenities. The results of the legality discussion were related to licensing and the legality of Glamping De Loano, which was related to the legality of the Glamping De Loano nomadic tourism development program which was hampered by the high level, between ministries or national government level, while there is good cooperation and direct coordination with the Regional Government or Village Government to facilitate the license. Land ownership should be private land because this is the main problem of permits and regulations that are binding and regulate every step and initiative, regardless of whether these regulations are prepared to protect and preserve natural reserves. 
SWOT Analysis Nomadic Tourism as Millennial Friendly Natural

Tourist Destination Development Strategy

(Case Study: Glamping De Loano, Purworejo)

Glamping De Loano obstacles in carrying out its development and operations because the land belongs to Perhutani (Perusahaan Hutan Negara Indonesia), so it is better, as previously mentioned, so that permits and regulations are made easier to carry out the licensing process recommended by the Village Government or Local Government to facilitate future management. The thing that is being the consideration about the legality and licensing of Glamping is that the Glamping permit requires a special standard and legality that must be met because it has a big risk of damaging the environment and killing the economy and the survival of the surrounding community. Despite a fine reason regarding strict legality, however, this considers a possible threat to innovate new initiatives in the area due to the long process of legality.

The results of the next discussion were related to the design and theme of the amenities for Glamping De Loano is the structure of the amenities for nomadic tourism which could be temporary or semi-temporary with the use of materials that blend with nature, which can provide a different concept of natural attractions that tourists are looking for. What makes Glamping De Loano unique is the different experiences and sensations that travelers are looking for. Temporary structures help to innovate and adapt and develop increasingly developing trends.

A safe choice and strong durability, but unfortunately one of the risks of using biophilic or materials that blend with nature is regarding the climate or environmental factors that must be assessed before determining the type of tent or variant of nomadic amenities that is good to develop in the area. This is evident from the neglected condition of the glamping tent which causes the tent to become moldy. This is also able to bring possible threats to the business, Glamping itself is the main attraction of Glamping De Loano, however, due to lack of knowledge and lack of expertise, the uniqueness of glamping's material can bring negative impact.

Glamping itself has the nickname "nature on a silver plate" or "when nature meets luxury" which marks a new chapter in the development of the world of tourism. Glamping is suitable for the characteristics of the amenities of nomadic tourism, namely amenities that are environmentally friendly so that it is safe to be placed in the forest so that it can still offer a comfortable and even luxurious stay experience in the forest. This view is the view of the speakers who agree that glamping is concerned with natural attractions and glamping brings a new tourism style to natural attractions. Glamping considers a luxury in the open natural area which gives a new atmosphere especially for the area in Purworejo.

The management team of Glamping De Loano said that there were tourists who had come to Glamping De Loano with the expectation to be away from the hustle and bustle and modernization of life. There are two views of the design and themes that can be offered, namely the development of glamping in natural 
SWOT Analysis Nomadic Tourism as Millennial Friendly Natural

Tourist Destination Development Strategy

(Case Study: Glamping De Loano, Purworejo)

locations, offering a variety of attractive attractions, and developing glamping in natural locations that focus on developing the facilities offered in the glamping.

Referring to (BOB, 2019), this happens because the humidity level is very high and rarely gets direct sunlight, which triggers the appearance of mold in some accommodations. This biophilic tent made of the canvas has an aesthetic design but is prone to fungi. One of the points of discussion is the need for education and habits related to glamping care. Especially Glamping, which is located in cultural heritage, so the right treatment must be sought that does not damage the environment.

The next discussion was to discuss the importance of authenticity. The view related to attractions with local content which are the main attraction or only as a supporting attraction because the local attractions can indeed act as the identity of a place, but the most important thing is about the development of Glamping, especially Glamping De Loano's main objective is to give tourist satisfaction, namely providing the best quality for Glamping amenities considering that the main objective of developing these destinations is focused on alternative amenities.

The next discussion is the discussion facility, facilities related to the need for an amphitheater or having a large enough open-space called an amphitheater with a function that is quite crucial and can provide added-value associated with Glamping De Loano which can increase tourists in the form of groups to come and visit because it can be used to offer outdoor or outbound activities. The amphitheater can become additional revenue to the business, Glamping De Loano because it can attract groups in form of a company or community to book the spot and doing group activities there.

Glamping tents can indeed be said to be a solution to sustainable tourism building using nature-based infrastructure that can be moved easily, has beautiful aesthetics, but maintenance that is not carried out routinely and responsibly can risk causing environmental damage. The concern is that chemical cleaning solutions used in large volumes are not necessarily clean solutions for tents, but they damage the soil and the environment. One of the points that must be considered regarding the design and theme of the facility is that in addition to the exterior and good arrangement for glamping, it is also related to the knowledge, responsibility, and care of the glamping tent.

The next discussion is related to amenity services, which is related to one thing that can be emphasized is related to the provision of local culinary delights as part of the characteristics of a destination or region. It is very important because each region has its cultural potential and makes it the identity of each region, not to mention the development of nomadic tourism aims to provide benefits to the surrounding community. 
SWOT Analysis Nomadic Tourism as Millennial Friendly Natural

Tourist Destination Development Strategy

(Case Study: Glamping De Loano, Purworejo)

Culinary can also be provided by providing a cafeteria which is considered crucial to serve a variety of local culinary delights where the food ingredients are produced directly from the area. It is better if you synergize with the surrounding community to work with the local community to produce special culinary delights to be served to tourists. Especially considering that Purworejo has a variety of unique culinary delights.

Does not change the original identity of the community that becomes one of the means to preserve the country's tourism. The element that is lacking from Glamping De Loano that would be great to develop is Glamping De Loano can learn to integrate or create a strong synergy between nomadic amenities and the indigenous tribes of the area, which are not damaging to the environment and able to preserve the local community, as well. This will not only offer its uniqueness and attractiveness, but also become a tourism solution that helps to preserve the environment and local wisdom, but also provides economics as well as social and cultural benefits because it provides opportunities for interaction between local people and tourists.

The next discussion regarding amenity services is related to offline and online reservations where both forms of reservation are considered important. Offline reservations are considered important for overland travelers and only decide on an itinerary while on the go. Online reservation service that serves to make it easier for tourists to make reservations and encourage tourist visits.

The next discussion is related to the safety and security of amenities, this is an element that is crucial and should be the topic that is being discussed because the location of Glamping is in the remote area to be exact in the middle of a forest and it is located far from civilization. Each glamping unit within the area is located far from one glamping site to another, which also contributes to the preventive needs. Fear of unexpected accidents, wild animals, or disasters should be some of the factors that deserve attention.

\section{Analysis of the Readiness of Nomadic Tourism Attractions}

Analysis of the readiness of nomadic tourism attractions consisting of an inventory of attractions; experience tourist attractions; interpretation of attractions; access to attractions; and the security and safety of attractions. Discussions related to the analysis of attraction inventories centered on views related to the need for the map of the distribution of tourist attractions and information on tourist attractions which consist of natural attractions, cultural attractions, and artificial attractions around Glamping De Loano which can only be a supporting attraction for Glamping De Loano.

Discussions related to tourist experiences related to the attractions offered are various and adapted to the characteristics of nomadic tourists who are looking for natural, cultural, and adventure attractions. The discussion focused on the 
SWOT Analysis Nomadic Tourism as Millennial Friendly Natural

Tourist Destination Development Strategy

(Case Study: Glamping De Loano, Purworejo)

importance of elements of the three attractions in nomadic tourism, especially Glamping De Loano. Good attractions provided are adventure attractions that can provide a tourist experience that can offer sensations and experiences and provide a feeling of security when traveling.

This has been offered through an off-road experience which is the result of collaboration with the surrounding village community, namely Nglinggo Village. The next attraction is an experience that can provide tourists the opportunity to engage with local communities directly. This has been offered through live-in experiences and educational tours in Nglinggo Village. The next attraction is an experience that can allow tourists to enjoy the beauty of nature. This has been agreed as the main element in nomadic tourism as well as being the main element of Glamping De Loano, besides Glamping De Loano is indeed crushed by various natural attractions, but the location of Glamping De Loano in the middle of a pine forest is also unique, namely natural attractions that can be enjoyed in forms of amenities. Regarding natural attractions, Glamping De Loano can focus on combining natural attractions with amenities.

Discussions related to local content that attracted the attention of the community also contributed to the fact that Glamping De Loano did not yet have a regular and scheduled local show schedule. Glamping De Loano has just presented two Lengger Topeng dance performances that were held at the Glamping De Loano amphitheater, but they were still unintentional or unplanned and performed on request.

The method presented by (Kartika \& Rahmanita, 2017), Jaipong regional dance performances, and a very unique art theater has an attraction that can attract tourists and become the strongest aspect of Karawang Regency. So far, Jaipong dance and theater itself is often staged and preserved by the Karawang Regency Culture and Tourism Office and cultural actors, but many prospective tourists do not see it because of the lack of publications regarding staging schedules and locations. So it is unfortunate if the high interest in Jaipong dance performances and theater arts is difficult to drain water properly. Therefore it will be well preserved if Glamping De Loano presents local performances in collaboration with the surrounding community which will greatly help attract tourists who come to Glamping De Loano and also become a way to preserve local culture.

Discussions related to tourist experiences, one of the elements being the focus of attention is cultural attractions because cultural identity is an important element of nomadic tourism in addition to alternative amenities. Therefore, the tribe which is the identity of the area must be a priority for the development of the area. Things that can be improved are the routine and scheduled procurement of local content that involves the surrounding community. 6 villages have the potential to add value to the attractiveness of Glamping De Loano, namely 6 villages with single destination management of Gelang Projo.

Tourism Research Journal, Volume 5 (2), 2021 
SWOT Analysis Nomadic Tourism as Millennial Friendly Natural

Tourist Destination Development Strategy

(Case Study: Glamping De Loano, Purworejo)

Discussions related to the interpretation of attractions, one of the manifestations is the independent attraction signboard which is devoted to Glamping De Loano only and is clear enough to see because of its characteristic as guide information that makes it easier for tourists to get to the location.

Discussions regarding the interpretation of attractions, one important thing to consider is the use of natural materials. One of the things to consider is the location of Glamping De Loano which is in the middle of the forest and this serves to reduce environmental damage as well.

The discussion on the interpretation of attractions, the highlight is the provision of tourist attraction information whose function will provide additional information and knowledge for tourists to know more about Glamping De Loano and its surroundings. Information boards can also be a medium for storytelling so that the Glamping De Loano destination is not only seen as a place but there is a story behind it that makes Glamping De Loano have a "living" impression that makes the destination attractive and has more appeal. Information boards will also help tourists to dig deeper regarding these tourist attractions which will help tourists to determine which attractions can be visited around the Glamping area.

Information boards can also be equipped with the provision of do's and don'ts boards that can also serve to provide education about the attractions or stories and history of these locations, apart from the information boards in the Glamping area of the Ministry of Tourism which contain some information on nomadic tourism, however, it is better if the attractions and original stories from the area are also raised because this can be a means of educating tourists and the public to understand the culture and preserve the environment. The results of the discussion related to tourist guide boards regarding do's and don'ts, referring to the results of interviews with millennial tourists, he argued that the board regarding regulations for tourists or visitors cannot be ignored, not only for formality but will be useful for visitors to respect and obey community customs. around.

The next discussion is related to attraction access, the most important thing to consider regarding attraction access is the security and safety of attractions which are reflected in the quality of nomadic attractions. Nomadic attractions that are challenging in nature are allowed to build less smooth access because they will provide a challenging yet safe tourist experience. This has led to discussions regarding the obligation to pay attention to security and safety because of the characteristics of nomadic tourists who have an interest in adventure tourism and are looking for memorable experiences but still make comfort and security a priority factor.

This is to make it easier for tourists to give a feeling of security while providing opportunities for tourists to go to their destination. The safety and security aspects of the mandatory attractions are also related to the discussion that Glamping De Loano has not implemented strict safety standards and provides a

Tourism Research Journal, Volume 5 (2), 2021 
SWOT Analysis Nomadic Tourism as Millennial Friendly Natural

Tourist Destination Development Strategy

(Case Study: Glamping De Loano, Purworejo)

feeling of security and comfort. The security referred to is not only related to security guards but also related to security from wild animals and disasters such as fallen trees, fires, etc. There is even a sense of being threatened from fear of the spiritual world due to the location in the forest, giving rise to a haunted impression even though the location is comfortable and the lighting is sufficient.

\section{Nomadic Tourism Accessibility Readiness Analysis}

The accessibility readiness analysis consists of accessibility connectivity; accessibility transportation management; accessibility safety and security. The results of the discussion regarding accessibility connectivity were related to the location of Glamping De Loano which is indeed in a strategic location between New Yogyakarta International Airport/NYIA and was indeed built to support the presence of NYIA airport. This NYIA airport serves as both a domestic airport and an international airport with Borobudur. This is one of the things that supports nomadic tourism destinations to become the leading destination.

The discussion of accessibility connectivity which is the root of the main problem is access to locations that require major improvement. Access roads are narrow, winding, and quite dangerous which can affect the motivation of tourists to come to their destination. The development of road access infrastructure is important. This builds more entrances to destinations but also provides comfort and safety in driving to destinations. The biggest challenge of Glamping De Loano is the road infrastructure development that is narrow and small, it can be packaged and used as a force. One way to sell it is to make this lack of accessibility that challenging paths are part of the challenging nomadic tourism experience.

The results of the accessibility discussion are also related to transportation to the location. This is also part of the consideration of tourists and guests to come to destination locations. Glamping De Loano already provides public transportation to the destination location but it is still exclusive and requires reservation.

The results of the discussion on safety and accessibility are the most important things seen from experiencing obstacles with the narrow and steep Glamping De Loano road infrastructure so that the best solution if the tow truck facilities and complete information regarding access to Glamping De Loano will greatly help tourists who experience difficulty finding a destination or experiencing obstacles while traveling. The results of the discussion related to accessibility, apart from the process of improving road infrastructure to Glamping De Loano, the safety and security aspects of accessibility must be carried out simultaneously. The complaints that many sources conveyed were related to the accessibility of Glamping De Loano, which was far from perfect, but the source still accepted this condition. However, over time, it is possible for business competition to occur 
SWOT Analysis Nomadic Tourism as Millennial Friendly Natural

Tourist Destination Development Strategy

(Case Study: Glamping De Loano, Purworejo)

and the shortage of Glamping De Loano regarding the element of accessibility could backfire on the business against Glamping De Loano.

Accessibility becomes the main weakness for Glamping De Loano due to the road infrastructure that becomes one of the basic infrastructures regarding access to the location. It is possible for business competition to occur and the shortage of Glamping De Loano regarding the element of accessibility could backfire towards the business against Glamping De Loano.

\section{Analysis of the Readiness of Nomadic Tourism Supporting Ecosystem}

Supporting ecosystem analysis consists of the ecosystem supporting infrastructure; security and safety of ecosystem support; facilities and information for tourists supporting the ecosystem; empowerment and community support for ecosystems; ecosystem support regulations and permits; ecosystem support waste management; and marketing and promotion of ecosystem support.

The results of the discussion related to supporting ecosystem are the importance of fulfilling all the basic requirements to support the supporting ecosystem, which is to support business operations, such as the availability of clean water, availability of electricity, availability of clean and adequate public toilets, availability of telecommunications networks (signal and internet), availability of materials. raw materials/supplies such as traditional markets, modern markets, minimarkets, gas stations, petrol, and water filling facilities, as well as the availability of ATMs. Some of the supporting facilities have been fulfilled but are not fully private, for example, the distribution of electricity or the internet which is the result of cooperation with Diskominfo Purworejo.

The results of the discussion said that one of the facilities that played a big role was the availability of telecommunications networks (signals and the internet), apart from the millennial market share, but in reality, in the era of advancement in communication, the internet was already a part of life. By procuring a better telecommunication network (signal and internet), it will provide opportunities to open serious leisure opportunities or destinations for guests who want to take a vacation while working. This can also open up opportunities to facilitate promotion through social media, especially seeing the close relationship between millennials and social media.

The results of discussions related to marketing and promotion as part of the supporting elements of the ecosystem are also one of the topics that are of concern and are considered important. An important element that is considered important is the focus on producing creative content, especially to attract the millennial market, open other social media channels, and develop a marketing approach that focuses on millennials. Marketing through social media has the potential to be a big investment in the future because it will help Glamping De 
SWOT Analysis Nomadic Tourism as Millennial Friendly Natural

Tourist Destination Development Strategy

(Case Study: Glamping De Loano, Purworejo)

Loano to adapt to the times, make changes/innovate so as not to lose in business competition/competition in the future.

One of the most important elements that should become the focus of developing nomadic tourism is the community development area as one of the most crucial parts, it is mentioned that community training regarding specific skills is necessary, however, external parties or the management itself to give the supporting assistance to the local community. It would be beneficial for the community to be able to play an impactful role to the Glamping De Loano as a supporting attraction which would help to also gives impactful economic development towards the area since Glamping De Loano would play as an important tourist attraction to the area and community would be beneficial to give advantage to the local society.

\section{E. Conclusion}

Considering the field studies, the analysis of in-depth theories of SWOT analysis for strengths, weakness, opportunity, and threat, seeing from the internal factors which are strengths and weaknesses. The strengths of Glamping De Loano, it is the strategic location with the concept of amenities for nomadic tourism that offers a unique natural tourist attraction concept that is rich in potential supporting attractions that get full support from various parties ranging from the central government, regions, villages, and the surrounding community. Based on the weaknesses of nomadic tourism, it is glamping resistance which is influenced by routine glamping maintenance, lack of exploration and utilization of attractions, road access that is still extreme, steep, and steep, and limited glamping supporting facilities.

Seeing from the external perspectives which are the opportunity and the threat, Based on the opportunities for amenities, accessibility, attractions, and supporting ecosystems, collaboration with various parties is to develop each element of nomadic tourism. Based on the threat of nomadic tourism, natural factors, competition, and openness, and community acceptance.

The strategies that are being offered for Glamping De Loano can be seen from every tourism element combine with SWOT analysis. However, Glamping De Loano is categorized as an early-stage destination because it has only been operated for less than a year but has many opportunities that can be cultivated and developed. Thus, the priority of developing the right elements of nomadic tourism for Glamping De Loano is the priority for the development of supporting the nomadic tourism ecosystem. Once this fulfills it would be helpful to set a great foundation for Glamping De Loano's development and sustainability since it is proven that Glamping De Loano has sets of potentials that awaiting to be discovered.

Tourism Research Journal, Volume 5 (2), 2021 
SWOT Analysis Nomadic Tourism as Millennial Friendly Natural

Tourist Destination Development Strategy

(Case Study: Glamping De Loano, Purworejo)

\section{REFERENCES}

Badan Otorita Borobudur. (2019). Glamping De Loano Jadi Destinasi Baru di Bukit Menoreh. Retrieved June 12, 2021, from bttps:// bob.kemenparekraf.go.id/1362-glamping-de-loano-jadi-destinasi-baru-dibukit-menoreh/.

Ferreira, P., Helms, K., Brown, B., \& Lampinen, A. (2019). From Nomadic Work to Nomadic Leisure Practice: A Study of Long-term Bike Touring. Proceedings of the ACM on Human-Computer Intersction, 3: 111:1-111:20

Hermawan, B., Salim, U., Rohman, F., \& Rahayu, M. (2016). Borobudur Temple as Buddhist Pilgrimage Destination in Indonesia: an Analysis of Factors that Affect Visit Intention. Journal of International Buddhist Studies, 7 (2): 98 110.

Hidajat, W. K., Anggoro, S., \& Najib. (2020). Management of Coastal Areas with Sustainable Marine Ecotourism Development in Purworejo Regency, Central Java, Indonesia. Advance Sustainable Science, Engineering and Technology: 0200105(01)-0200105(08).

Gatra.com. (2019). Bersiap Kemping ke De Loano, Kemah Mewah di Zona Otorita Borobudur. Retrieved May 25, 2021, from bttps:/ / www.gatra.com/ detail/ news/388942-Bersiap-Kemping-ke-De-LoanoKemah-Mewah-di-Zona-Otorita-Borobudur.

Kartika, D. G., \& Rahmanita, M. (2017). Analisis Komponen Produk Wisata di Kabupaten Karawang. Jurnal Ilmiah Pariwisata, 22(3): 123-131.

Kemenpar. (2018). Nomadic Tourism. Jakarta : Kementerian Pariwisata Republik Indonesia

Kemenpar. (2019). Panduan Teknis Pengembangan Pariwisata Nomadic. Jakarta: Kementerian Pariwisata Republik Indonesia

Mahadewi, N. M. E. (2019). Nomadic Tourism, Education Tourism, Digital Tourism and Event Tourism for Sustainable Tourism. Jour of Adv. Research in Dynamical \& Control Systems, 11(11): 360-367.

Pemkab Purworejo. (2021). Glamping De Loano Akan Terus Dibenahi. Retrieved July 17, 2021, from https://purworejokab.go.id/web/read/1777/glamping-deloano-akan-terus-dibenabi-.html.

Prabawa, I. W. S. W., \& Pertiwi, P. R. (2020). The Digital Nomad Tourist Motivation in Bali: Exploratory Research Based on Push and Pull Theory. Athens Journal of Tourism, 7(3): 161-174.

Pramono, J., Sumartaha, I. M., Santoso, I.M., Herlambang, P. G. D., \& Purwantoro, B. (2020). Destination Successes Factors for Millennial Travelers Case Study of Tanah Lot Temple, Tabanan, Bali. ADI Journal on Recent Innovation (AJRI), 1(2): 136-146.

Tourism Research Journal, Volume 5 (2), 2021 
SWOT Analysis Nomadic Tourism as Millennial Friendly Natural Tourist Destination Development Strategy (Case Study: Glamping De Loano, Purworejo)

Rahmanita, M. (2015, November 11). Pariwisata Sebagai Leading Sector: Tantangan dan Agenda Strategis. Harian Ekonomi Neraca. Retrieved July 26, 2021, from bttps:/ / www.neraca.co.id/article/61279/pariwisata-sebagai-leading-sectortantangan-dan-agenda-strategis

Rangkuti, F. (2015). Analisis SWOT Teknik Membedah Kasus Bisnis. Jakarta: Gramedia Pustaka Utama

Sari, G. B. P., Rahardjo, P., Wirawati, S. (2019). Pengembangan Kawasan Wisata Borobudur Highland Dengan Konsep Nomadic Tourism (Objek Studi: Zona Otorita Kawasan Pariwisata Borobudur, Kabupaten Purworejo, Jawa Tengah). Jurnal Stupa, 1(2): 2217-2228.

Tunjungsari, K. R. (2020). Tourism Development For Taman Wisata Candi Borobudur (TWCB). Jurnal Hopitality dan Pariwisata, 6 (1): 47-55.

Tourism Research Journal, Volume 5 (2), 2021 